\title{
An Assessment of Energy-Related Career Paths of Senior Industrial Assessment Center Program Alumni
}

December 2002

\author{
Prepared by \\ Jean H. Peretz \\ Bruce E. Tonn \\ University of Tennessee, Knoxville \\ Michaela Martin \\ Oak Ridge National Laboratory
}




\title{
DOCUMENT AVAILABILITY
}

Reports produced after January 1, 1996, are generally available free via the U.S. Department of Energy (DOE) Information Bridge:

Web site: http://www.osti.gov/bridge

Reports produced before January 1, 1996, may be purchased by members of the public from the following source:

\author{
National Technical Information Service \\ 5285 Port Royal Road \\ Springfield, VA 22161 \\ Telephone: 703-605-6000 (1-800-553-6847) \\ TDD: $703-487-4639$ \\ Fax: 703-605-6900 \\ E-mail: info@ntis.fedworld.gov \\ Web site: http://www.ntis.gov/support/ordernowabout.htm
}

Reports are available to DOE employees, DOE contractors, Energy Technology Data Exchange (ETDE) representatives, and International Nuclear Information System (INIS) representatives from the following source:

Office of Scientific and Technical Information

P.O. Box 62

Oak Ridge, TN 37831

Telephone: 865-576-8401

Fax: 865-576-5728

E-mail: reports@adonis.osti.gov

Web site: http://www.osti.gov/contact.html

This report was prepared as an account of work sponsored by an agency of the United States Government. Neither the United States government nor any agency thereof, nor any of their employees, makes any warranty, express or implied, or assumes any legal liability or responsibility for the accuracy, completeness, or usefulness of any information, apparatus, product, or process disclosed, or represents that its use would not infringe privately owned rights. Reference herein to any specific commercial product, process, or service by trade name, trademark, manufacturer, or otherwise, does not necessarily constitute or imply its endorsement, recommendation, or favoring by the United States Government or any agency thereof. The views and opinions of authors expressed herein do not necessarily state or reflect those of the United States Government or any agency thereof. 


\title{
AN ASSESSMENT OF ENERGY-RELATED CAREER PATHS OF SENIOR INDUSTRIAL ASSESSMENT CENTER PROGRAM ALUMNI
}

\author{
Jean H. Peretz \\ Bruce E. Tonn \\ UNIVERSITY OF TENNESSEE, KNOXVILLE \\ Michaela Martin \\ OAK RIDGE NATIONAL LABORATORY
}

December 2002

Prepared by

OAK RIDGE NATIONAL LABORATORY

P.O. Box 2008

Oak Ridge, Tennessee 37831-6285

managed by

UT-Battelle, LLC

for the

U.S. DEPARTMENT OF ENERGY

under contract DE-AC05-00OR22725 



\section{CONTENTS}

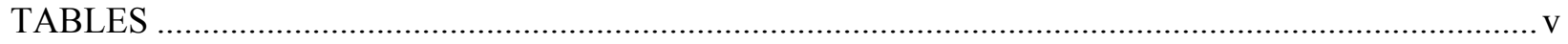

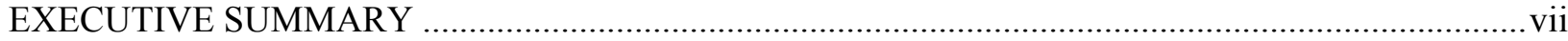

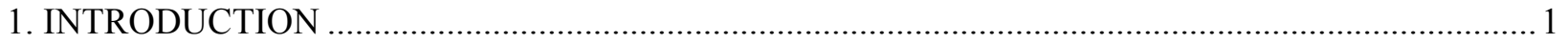

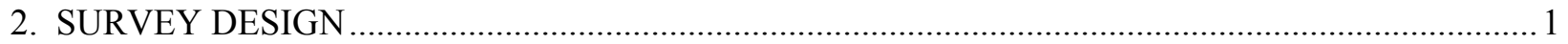

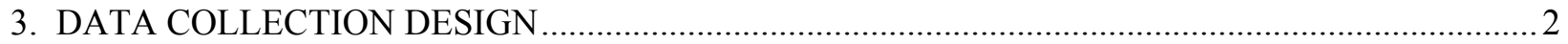

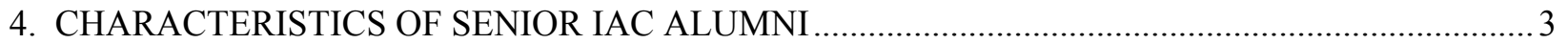

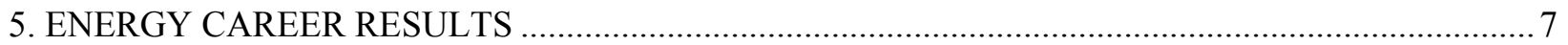

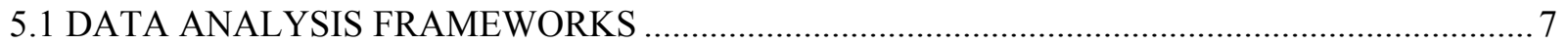

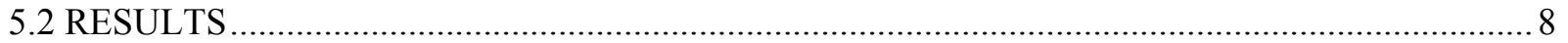

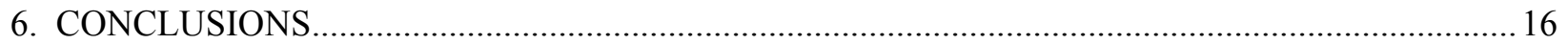

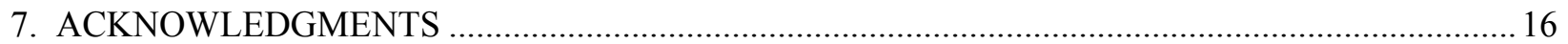

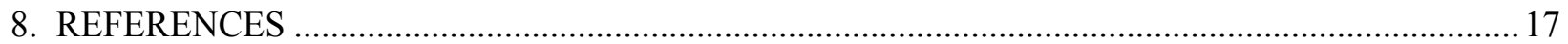

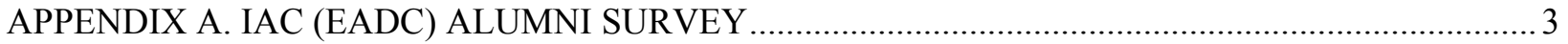





\section{TABLES}

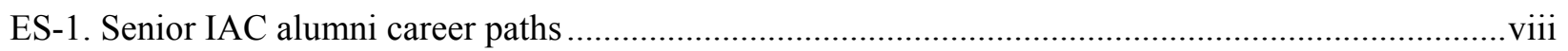

ES-2. Descriptive characteristics of senior IAC alumni career paths ....................................................viii

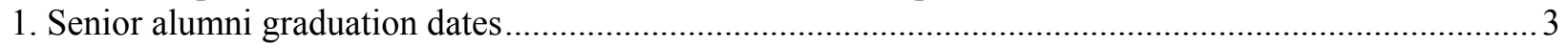

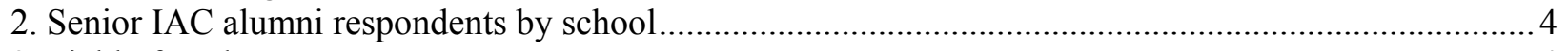

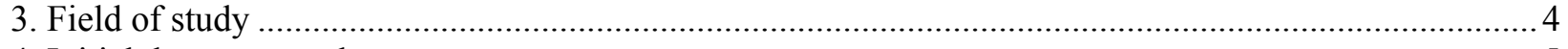

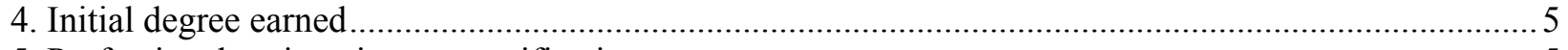

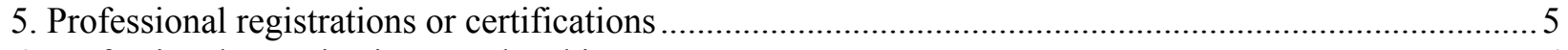

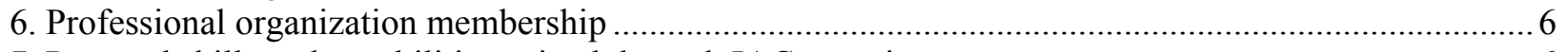

7. Personal skills and capabilities gained through IAC experience ….................................................... 6

8. Category 1-Have Not Pursued Energy-Related Career ..................................................................... 9

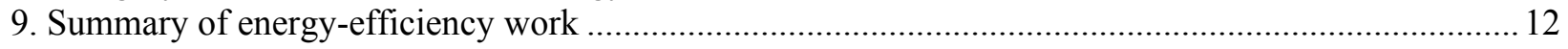

10. Changes in methods of influencing energy efficiency over career ................................................ 14

11. Methods of influencing energy efficiency by positions in organizations .......................................... 15 



\section{EXECUTIVE SUMMARY}

The purpose of this study was to assess the career paths of senior student alumni who participated in the U.S. Department of Energy's Industrial Assessment Center (IAC) Program. A survey was conducted last year of senior IAC alumni, defined as those graduating from college in 1995 or earlier. University of Tennessee researchers contacted 51 senior alumni; 33 (65\%) of these participated in the survey. The range of graduation dates was 1981 to 1995, with a mean graduation date of 1991. Respondents represented 14 different schools. All respondents reported engineering as their field of study, with most $(82 \%)$ being mechanical engineers. These respondents have achieved numerous professional registrations and certifications and are active in at least 15 professional organizations.

We developed two frameworks to guide data analysis. One framework describes career paths of senior IAC alumni. Alumni fell into one of four career path categories: no job experience related to energy-efficiency; initial job responsibilities related to energy-efficiency but have since transitioned to other responsibilities; initial job responsibilities not related to energy-efficiency but have since transitioned to positions involving energy-efficiency; and entire career has involved jobs with energyefficiency responsibilities. The second framework describes types of job responsibilities related to energy-efficiency and encompasses the following six categories: energy assessments; teaching and training; outreach and technology transfer; research and financial evaluation; construction, operation, maintenance, or repair; and design.

Table ES- 1 describes how the 33 respondents fell into the four career path categories. Some $58 \%$ have had jobs that entailed energy-efficiency responsibilities throughout their careers and $73 \%$ currently have such jobs. Only seven alumni (or $21 \%$ ) have never had a job that included responsibilities related to energy-efficiency. Also indicated in Table ES-1 are the average number of jobs held and the average tenure in years of those jobs related to energy-efficiency for the last three categories of respondents. Presented last are years since graduation. One alumnus reported being involved with energy-efficiency activities 20 years after graduation. Based on this finding, it can be extrapolated that some IAC alumni could be involved with energy-efficiency their entire careers, until retirement, covering a span of 40 years or more.

Table ES-2 presents information about the types of positions held by senior IAC alumni. Those who have spent their careers in positions related to energy-efficiency work for a wide range of employers, have a wide range of job responsibilities, and employ numerous methods to influence energy efficiency. All groups of alumni continue to conduct energy assessments. All stated that their IAC experience was very relevant to their career paths. Some alumni have moved up in their organizations, but relatively few have moved beyond first-level supervisory positions. Other information indicates that all positions in organizations involve energy assessments, from entry level to top management. However, many senior IAC alumni assume responsibilities for research and financial evaluation, as well as construction, operations, maintenance, or repair. These might be suitable topics for a continuing education program, along with sessions on the latest energy-efficient technologies, processes, and techniques. 
Table ES-1. Senior IAC alumni career paths

\begin{tabular}{lcccc}
\hline Category & $\begin{array}{c}\text { No energy- } \\
\text { efficiency } \\
\text { responsibilities }\end{array}$ & $\begin{array}{c}\text { Initial energy- } \\
\text { efficiency } \\
\text { responsibilities }\end{array}$ & $\begin{array}{c}\text { Later energy- } \\
\text { efficiency } \\
\text { responsibilities }\end{array}$ & $\begin{array}{c}\text { Entire career } \\
\text { energy-efficiency } \\
\text { responsibilities }\end{array}$ \\
\hline Total alumni & $7(21 \%)$ & $2(6 \%)$ & $5(15 \%)$ & $19(58 \%)$ \\
$\begin{array}{l}\text { Average number of positions } \\
\text { held }\end{array}$ & $\mathrm{n} / \mathrm{a}$ & 3.0 & 2.8 & 3.0 \\
$\begin{array}{l}\text { Average length of positions } \\
\text { related to energy-efficiency } \\
\text { (years) }\end{array}$ & $\mathrm{n} / \mathrm{a}$ & 3.0 & 4.0 & 9.8 \\
$\begin{array}{l}\text { Years since graduation: mean } \\
\text { (min-max) }\end{array}$ & $12(7-16)$ & $9(8-10)$ & $11(7-15)$ & $11(7-21)$ \\
\hline
\end{tabular}

From this information, it can be concluded that a significant portion of senior IAC alumni continues to influence workplace energy-efficiency in a wide variety of positions and in a wide variety of manners.

Table ES-2. Descriptive characteristics of senior IAC alumni career paths

\begin{tabular}{|c|c|c|c|}
\hline Category & $\begin{array}{l}\text { Initial energy- } \\
\text { efficiency } \\
\text { responsibilities }\end{array}$ & $\begin{array}{l}\text { Later energy-efficiency } \\
\text { responsibilities }\end{array}$ & $\begin{array}{c}\text { Entire career energy-efficiency } \\
\text { responsibilities }\end{array}$ \\
\hline Employers & $\begin{array}{l}\text { Small, medium } \\
\text { industrial or } \\
\text { manufacturing } \\
\text { - University, college, } \\
\text { other post-secondary } \\
\text { institution }\end{array}$ & $\begin{array}{l}\cdot \text { Consulting } \\
\cdot \text { Energy service company } \\
\text { - Large industrial or } \\
\text { manufacturing } \\
\cdot \text { University, college, other } \\
\text { post-secondary institution }\end{array}$ & $\begin{array}{l}\text { - Construction and/or design } \\
\text { - Consulting } \\
\text { - Electric power/utility } \\
\text { - Energy service company } \\
\text { - Government (federal, state, or local) } \\
\text { - Large commercial business } \\
\text { - Large industrial/manufacturing } \\
\text { - University, college, other post-secondary } \\
\text { institution }\end{array}$ \\
\hline $\begin{array}{l}\text { Job } \\
\text { responsibilities }\end{array}$ & $\begin{array}{l}\cdot \text { Engineering } \\
\text { management } \\
\cdot \text { Productivity/process } \\
\text { engineering }\end{array}$ & $\begin{array}{l}\cdot \text { Business management } \\
\cdot \text { Consultant } \\
\cdot \text { Engineering management } \\
\cdot \text { Project engineer/project } \\
\text { manager } \\
\cdot \text { Research and development } \\
\cdot \text { Other - product } \\
\text { development }\end{array}$ & $\begin{array}{l}\cdot \text { Analyst } \\
\cdot \text { Business management } \\
\cdot \text { Consultant } \\
\cdot \text { Education/training } \\
\cdot \text { Engineering management } \\
\cdot \text { Facilities management } \\
\cdot \text { Project engineer/project manager } \\
\text { - Research and development } \\
\cdot \text { Sales } \\
\cdot \text { Technician } \\
\cdot \text { Other - product development }\end{array}$ \\
\hline $\begin{array}{l}\text { Methods of } \\
\text { influencing } \\
\text { energy } \\
\text { efficiency }\end{array}$ & Energy assessments & $\begin{array}{l}\text { - Construction, operation, } \\
\text { maintenance, or repair } \\
\cdot \text { Energy assessments } \\
\cdot \text { Teaching and training }\end{array}$ & $\begin{array}{l}\text { Construction, operation, maintenance, or } \\
\text { repair } \\
\text { - Design } \\
\cdot \text { Energy assessments } \\
\cdot \text { Outreach and technology transfer } \\
\cdot \text { Research and financial evaluation } \\
\cdot \text { Teaching and training }\end{array}$ \\
\hline $\begin{array}{l}\text { Organizational } \\
\text { hierarchy for } \\
\text { current position }\end{array}$ & $\begin{array}{l}\cdot \text { Entry level } \\
\cdot \text { First-level supervisor }\end{array}$ & $\begin{array}{l}\cdot \text { First-level supervisor } \\
\cdot \text { Middle management } \\
\cdot \text { Top management }\end{array}$ & $\begin{array}{l}\cdot \text { Entry level } \\
\cdot \text { First-level supervisor } \\
\cdot \text { Middle management } \\
\cdot \text { Top management }\end{array}$ \\
\hline
\end{tabular}


Finally, IAC is implementing several operational changes to improve the prospects for students to obtain and retain jobs in energy efficiency. These include: attracting corporate recruiters, gaining recognition of the IAC program by state licensure boards, improving the IAC student database to be useful to alumni, and establishing a Student Steering Committee to provide suggestions to DOE and IAC Directors regarding program direction. 



\section{INTRODUCTION}

The purpose of this study was to assess the career paths of alumni from the U.S. Department of Energy's Industrial Assessment Center (IAC) program. IAC was originally named the Energy Analysis and Diagnostic Center (EADC) program when it began in association with four schools in 1976. The current IAC program provides funding to 26 engineering colleges, located in centers across the United States, to conduct energy, waste, and productivity assessments for small- to medium-sized manufacturing establishments within their respective regions. Through part-time employment with the university, students receive training and in turn conduct assessments for local manufacturers, under the direct supervision of engineering faculty. Annually, IAC participants conduct over 700 assessments, and each assessment generates recommendations for energy savings, energy cost savings, and waste and productivity cost savings customized for individual clients.

An earlier study determined that energy savings could be attributed to alumni of the IAC program who take their IAC experiences with them to the professional workplace. During their careers, the alumni conduct additional energy assessments as well as influence energy efficiency through design, teaching and training, and other activities. Indeed, a significant level of program benefits can be attributed to the alumni. This project addressed such specific questions as: How many years after graduation are IAC alumni involved in energy-efficiency activities? What different methods do they use to influence energyefficiency decisions? To answer these questions, the University of Tennessee, Knoxville (UT) surveyed IAC senior alumni, defined as those who graduated in 1995 or earlier.

Section 2 describes the survey used in this research. The actual survey can be found in Appendix A. Section 3 describes our approach to data collection. Section 4 presents descriptive statistics about the senior alumni who responded to the survey. Section 5 begins with the presentation of two frameworks used to help analyze the data about alumni career paths and then presents the career path results. Section 6 offers concluding remarks.

\section{SURVEY DESIGN}

The survey consists of 17 questions, 7 of which are repeated for each job held as reported by the survey respondents. The initial survey questions collect background information on respondent's degree program, graduation year, major degree, and how participation in IAC benefited respondent's professional skills and capabilities. Some questions also pertain to professional memberships and registration or certifications.

With regard to what percentage of respondents address energy concerns over their careers, we asked alumni to provide information on up to six positions held after their IAC participation. If alumni held more than six career positions since involvement with IAC, they were asked to summarize positions held about every three years. Regarding different methods of influencing energy-efficiency decisions for each position held over the years, we asked them to describe their involvement in energy-efficiency. We also collected information on the employer, job responsibilities, and where the position fit within the organization's hierarchy. Finally, we asked respondents to rank the relevance of their IAC experience to each position held. Because senior IAC alumni were trained only in energy efficiency (not productivity 
enhancement and waste reduction, which were added to the IAC program only recently), we focused entirely on energy efficiency.

\section{DATA COLLECTION DESIGN}

A total of 78 alumni graduating from college in 1995 or earlier were identified from a list of all IAC alumni collected by Rutgers University in 1997. Because of the desire for a high response rate, we decided to administer the survey via telephone (see Folz 1996 for expected response rates from different survey methods).

Of the 78 alumni listed, 69 included telephone numbers. A search on Internet-based telephone services did not reveal the missing telephone numbers when we searched by name and city address provided in the database. We began making telephone calls in late November 2001. Of the 69 numbers we dialed, 20 numbers had been disconnected, were incorrect with no further information, or were no longer in service. We continued to make calls to the remaining 49 through March 2002. For those with answering machines, we left messages identifying the purpose of the call, the university researcher conducting the interview, and contact information.

We e-mailed the questionnaire to those alumni who, although reached by telephone, opted to complete the questionnaire by e-mail. Between November 2001 and March 2002 we placed at least four calls to each senior alumnus or e-mailed a survey. Because the initial response rate via telephone was low, we decided to contact the non-respondents by mail. Our method for this process follows.

As part of a related project, all alumni in the list compiled by Rutgers received post cards seeking their participation in a Web-based survey. These cards were mailed in mid-January 2002; delivery/address confirmation cards were returned from the U.S. Postal Service at the end of January. From the post-card mailings, we compared returns from the U.S. Postal Service against our list of 78 . We found that 25 of these had undeliverable addresses, while another 2 had incomplete information in the Rutgers list (e.g., full names were not included, even though we had telephone numbers).

After at least four attempts at telephone contact, we mailed cover letters, surveys, and postage-paid return envelopes to the remaining non-respondents in mid-April, even if alumni had missing or incorrect telephone numbers identified through the telephone method. Follow-up post cards were mailed two weeks later. Through the telephone contacts, e-mails, and U.S. Postal Service mailing, $65 \%$ of those alumni contacted completed the questionnaire. This figure was calculated as follows:

Alumni identified in initial database $\quad 78$

Letters returned from U.S. Postal Service $\quad 25$

Incomplete contact information in Rutgers database 2

Total number of senior alumni contacted 51

Number of senior alumni who completed questionnaire $\quad 33$

Percent of those contacted who completed questionnaire $\quad 65 \%$ 


\section{CHARACTERISTICS OF SENIOR IAC ALUMNI}

Table 1 shows that nearly three-fourths of the respondents graduated from the IAC program with their first degree between 1990 and 1995. The mean graduation date is 1991, with a 3.97-year standard deviation. The distribution is similar to findings from previous studies (Martin et al. 1999) and parallels the increase in IAC participants over time. It also appears to reflect more accurate contact information. The complete range of graduation dates is 1981 through 1995.

Table 1. Senior alumni graduation dates

\begin{tabular}{ccccc}
\hline Year & Frequency & Percent & $\begin{array}{c}\text { Cumulative } \\
\text { Frequency }\end{array}$ & $\begin{array}{c}\text { Cumulative } \\
\text { Percent }\end{array}$ \\
\hline 1981 & 1 & 3.0 & 1 & 3.0 \\
1982 & 1 & 3.0 & 2 & 6.1 \\
1983 & 1 & 3.0 & 3 & 9.1 \\
1984 & 0 & 0 & 3 & 9.1 \\
1985 & 1 & 3.0 & 4 & 12.1 \\
1986 & 2 & 6.1 & 6 & 18.2 \\
1987 & 1 & 3.0 & 7 & 21.2 \\
1988 & 1 & 3.0 & 8 & 24.2 \\
1989 & 1 & 3.0 & 9 & 27.3 \\
1990 & 3 & 9.1 & 12 & 36.4 \\
1991 & 2 & 6.1 & 14 & 42.4 \\
1992 & 5 & 15.2 & 19 & 57.6 \\
1993 & 3 & 9.1 & 22 & 66.7 \\
1994 & 7 & 21.2 & 33 & 87.9 \\
1995 & 12.1 & & 100.0 \\
\hline & 5 & & 29 & \\
\hline
\end{tabular}

Of our 33 respondents, 4 participated in the IAC program during their undergraduate and graduate careers at the same university. Of these four who received graduate degrees, one graduated in 1983, one in 1990, one in 1995, and one in 2000. The 2000 graduate is included in our analysis for energy influence over the course of his career, as he received his undergraduate degree in 1994 and did graduate work parttime while employed in a full-time career position.

Table 2 lists the schools where our respondents participated in the IAC program. The majority participated at Colorado State University, but Bradley, Kansas, Texas A\&M, and Oregon State universities are well represented. 


\begin{tabular}{lcc}
\hline \multicolumn{1}{c}{ School } & Frequency & Percent \\
\hline Colorado State University & 8 & 24.2 \\
University of Kansas & 4 & 12.1 \\
Bradley University & 3 & 9.1 \\
Oregon State University & 3 & 9.1 \\
Texas A\&M University & 3 & 9.1 \\
Oklahoma State University & 2 & 6.1 \\
South Dakota State University & 2 & 6.1 \\
University of Missouri Rolla & 2 & 6.1 \\
Hofstra University & 1 & 3.0 \\
North Carolina State University & 1 & 3.0 \\
Mississippi State University & 1 & 3.0 \\
University of Arkansas Little Rock & 1 & 3.0 \\
University of Massachusetts & 1 & 3.0 \\
\hline
\end{tabular}

The overwhelming majority of our respondents earned degrees in mechanical engineering, as depicted in Table 3. Twenty-seven of the alumni majored in mechanical engineering, while the remaining 6 majored in industrial engineering, industrial engineering and management, electrical engineering, or architectural engineering. Most respondents (see Table 4) received Bachelor of Science degrees (64\%) as their first degree while participating in the IAC program, while 10 received Master of Science degrees, and 2 received Doctor of Philosophy degrees. Four participants in the IAC program received both bachelor and master degrees while participating in the program, as noted above.

Table 3. Field of study

\begin{tabular}{lcc}
\hline \multicolumn{1}{c}{ Field } & Frequency & Percent \\
\hline Mechanical Engineering & 27 & 81.8 \\
Industrial Engineering & 3 & 3.0 \\
Industrial Engineering and Management & 1 & 3.0 \\
Electrical Engineering & 1 & 3.0 \\
Architectural Engineering & 1 & 3.0 \\
\hline
\end{tabular}


Table 4. Initial degree earned

\begin{tabular}{lcc}
\hline \multicolumn{1}{c}{ Degree } & Frequency & Percent \\
\hline Bachelor of Science & 21 & 63.6 \\
Master of Science & 10 & 30.3 \\
Doctor of Philosophy & 2 & 6.1 \\
\hline
\end{tabular}

Upon graduation, more than $80 \%$ of our senior participants have gone on to professional registrations or certifications (Table 5). Most are professional engineers, while others are engineers in training and certified energy managers. Twelve of our participants hold 2 professional certifications or registrations; 2 hold 3.

Likewise, the participants have joined professional organizations. Twenty-eight hold memberships in at least 1 professional organization, while 15 hold memberships in least 2 professional organizations, and 9 have membership in 3 organizations (see Table 6). The majority belongs to the American Society of Heating, Refrigerating and Air-Conditioning Engineers, followed by the American Society of Mechanical Engineers and Association of Energy Engineers. IAC alumni hold membership in a total of 15 professional organizations.

Table 5. Professional registrations or certifications

\begin{tabular}{lcc}
\hline \multicolumn{1}{c}{$\begin{array}{c}\text { Professional registration or } \\
\text { certification }\end{array}$} & Frequency & Percent \\
\hline Professional Engineer & 18 & 54.5 \\
Certified Energy Manager & 4 & 12.1 \\
Engineer in Training & 5 & 15.1 \\
None & 6 & 18.1 \\
\hline
\end{tabular}




\begin{tabular}{lcc}
\hline \multicolumn{1}{c}{ Professional organization } & Frequency & Percent \\
\hline American Society of Heating, Refrigerating and Air-Conditioning & 15 & 25 \\
Engineers & 13 & 22 \\
American Society of Mechanical Engineers & 13 & 22 \\
Association of Energy Engineers & 2 & 3 \\
Society of Automotive Engineers & 1 & 1.7 \\
Instrument Society of America & 1 & 1.7 \\
American Society of Plumbing Engineers & 1 & 1.7 \\
National Council of Examiners for Engineering and Surveying & 1 & 1.7 \\
National Association of Energy Service Companies & 1 & 1.7 \\
Institute of Industrial Engineers & 1 & 1.7 \\
American Society for Engineering Education & 1 & 1.7 \\
International Ground Source Heat Pump Association & 1 & 1.7 \\
National Society of Professional Engineers & 1 & 1.7 \\
St. Louis Regional Green Building Council & 1 & 1.7 \\
Society of Women Engineers & 1 & 1.7 \\
American Solar Energy Society & 5 & 8 \\
None & 1 & \\
\hline
\end{tabular}

Finally, we asked the alumni an open-ended question: What personal skills and capabilities were enhanced as a result of your participation in the IAC program? We then grouped the results by primary subject matter. Table 7 presents those results. They represent engineering skills as well as personal skills gained.

Table 7. Personal skills and capabilities gained through IAC experience

\section{Personal Skills and Capabilities}

Number of

Observations

Verbal and written communication skills

Research and technical analysis skills 16

Understanding of various manufacturing procedures and their effects on energy use 7

Enhancement of engineering knowledge and information gained in class in an industrial setting 6

$\begin{array}{ll}\text { Teamwork } & 5\end{array}$

Energy consumption patterns and utility rate structures 4

Time management 4 


\begin{tabular}{lc}
\hline \multicolumn{1}{c}{ Personal Skills and Capabilities } & $\begin{array}{c}\text { Number of } \\
\text { Observations }\end{array}$ \\
\hline Assessment of industrial equipment & 2 \\
Energy-efficiency opportunities & 2 \\
Modeling and computer skills & 2 \\
Self-confidence & 2 \\
Organizational skills & 2 \\
Appreciation of various energy sources (solar, nuclear, electric) & 1 \\
Budgeting & 1 \\
\hline
\end{tabular}

\section{ENERGY CAREER RESULTS}

\subsection{DATA ANALYSIS FRAMEWORKS}

One task in this survey was to assess what percentage of senior IAC alumni had addressed energy concerns over their careers. One measure of effectiveness of the IAC program is the transfer of energyefficiency knowledge gained in the educational environment to workplace settings. Through the knowledge gained, former students can speed the incorporation of energy savings opportunities in industry and in other sectors of the economy. This diffusion of technological knowledge can contribute to economic development in the United States, as suggested in Martin et al. (1999). This does not eliminate the importance of other skills that are acquired through the IAC experience, e.g., communication skills; it simply suggests that the key component of the IAC experience is to incorporate energy-efficiency measures into an industrial setting.

Particularly since we were assessing career paths, we assumed that energy-efficiency-related activities would vary over the careers of IAC alumni from no energy focus at all to an entire career of energy-efficiency activity. Moreover, for an individual alumnus, we assumed that there would be variation across a career, e.g., one person worked in the energy-efficiency field at some point during a career, but not throughout the entire career. To handle this variation in career paths, we developed a framework to categorize types of career paths. Our framework poses these four categories:

- No job experience related to energy-efficiency. These alumni did not choose a career path that involved energy-related activities. It is assumed that their knowledge about energy-efficiency was not diffused to others. This does not imply that other skills learned through the IAC experience have not enhanced the alumni's career, e.g., technical writing or communication skills.

- Initial job responsibilities related to energy-efficiency but have since transitioned to other responsibilities. This category consists of those IAC alumni who entered the work force in an energyefficiency position. These alumni were employed in settings that offered opportunities to influence energy efficiency. However, during the course of their careers, there was a shift away from energyefficiency activity as a primary or secondary job responsibility.

- Initial job responsibilities were not related to energy-efficiency but have since transitioned to positions involving energy-efficiency. This is the opposite of the previous category. Here the alumnus entered the work force in a non-energy-efficiency-related position, but had opportunities to diffuse 
knowledge about energy-efficiency through changes in job responsibilities and/or employers.

- Entire career has involved jobs with energy-efficiency responsibilities. Here we assume that each position held by senior IAC alumni entailed energy-efficiency responsibilities.

We developed a second framework to capture the methods used for influencing energy-efficiency decisions over the years. Here we defined the methods rather broadly. The most obvious method comprises energy assessments and recommendations to clients, as the alumni were trained. However, we felt that there could be other methods that could influence energy efficiency, such as through residential or building construction, teaching undergraduate and graduate classes on energy-efficiency measures, research on energy-efficiency measures, maintenance of equipment for energy-efficiency, and calculating energy savings potential for utility clients. In the end, we devised six groupings of methods used for influencing energy-efficiency. These are:

- Energy assessments - energy evaluations or assessments, recommendations to clients and/or companies, and implementation related to recommendations

- Teaching and training — at an academic level through course work, consulting firm offering classes, training students on conducting assessments.

- Outreach and technology transfer - development of outreach programs on energy-efficiency, writing manuals, technology transfer of energy-savings opportunities.

- Research and financial evaluation - research on alternative energy systems, calculation of cost savings on investments in industrial energy-efficiency systems.

- Construction, operation, maintenance, or repair - for better efficiency, implementation of energyefficiency strategies within firm employed.

- Design - energy-efficiency systems for residential, commercial, or industrial buildings.

Obviously a person might be involved in more than one of the methods, even in one position. Moreover, we would expect changes in methods over a career. For example, an employee may begin providing technical assistance but then move into a training position. We would also expect people to change organizations during their careers.

We measured alumni activity in energy issues and methods of influencing decisions on energyefficiency by analyzing their responses to: "Please describe your involvement with energy-efficiency during your tenure in position no. _ (e.g., conducted assessments, approved purchases, implemented energy-efficiency strategies, etc.)." To confirm our interpretation of their responses, an engineer who had been involved in energy-efficiency measures over his career performed an independent review. His groupings matched ours.

\subsection{RESULTS}

No Job Experience Related to Energy-Efficiency. Of the 33 respondents to our survey, 7 (21\%) have not pursued any energy-related activities through their careers. Although they were complimentary of the IAC program and its ability to assist in career opportunities, they have not devoted any aspect of their careers energy-efficiency-related work. Table 8 summarizes their comments. Note that each who responded to an open-ended question on the IAC program was supportive of the program, observed that it assisted in career development, and recognized the potential for energy savings that could result from the IAC program. Even the respondent who did not believe that IAC lead to career advancements enjoyed the program. 
Table 8. Category 1-Have Not Pursued Energy-Related Career

Comments on IAC experience (7 observations)

Career path did not take me into energy-efficiency. There were no opportunities provided by the program. Although the program did not provide incentives for prospective employers when I graduated, I enjoyed the program. However, it did not lead to career advancements.

It was and continues to be a good program. The genuine impact is not what it should be, however, because of political/economic aspects of energy-efficiency. IAC as a social program is good but it does not meet its full potential.

Program should remain available to learning institutions. While many times intangible, skills learned through program are significant. I would like to offer my appreciation for being allowed to participate in the program. I would like to thank the program's leadership for organizing and operating such a well-run operation.

It was a worthwhile experience.

Although I have not gone into IAC-type jobs, the skills learned and honed have been valuable. I still have high interest in the area.

My involvement increased my understanding of business procedures relating to energy consumption, and I feel the experience was very beneficial. However, during my career my positions have not given me an opportunity to apply what I learned.

Even though I don't have any involvement with energy-efficiency, I know my EADC/IAC helped my engineering skills greatly. I have never been intimidated by any positions or challenges that have come my way.

Initial job responsibilities related to energy-efficiency but have since transitioned to other responsibilities. As displayed in Table 9, the two IAC alumni who addressed energy concerns in their first career positions provided energy assessments (leading assessments, soliciting companies for assessments, writing technical reports, approving procedures, and implementing energy strategies). The first alumnus held that position for 1 year; the second, for 5 years. Employers for these energy positions were (1) a university and (2) a small to medium industrial/manufacturing facility. The IAC experience was extremely relevant to the positions where the job responsibility was energy.

With regard to their assessments of the IAC program, one respondent indicated that the teamwork and communications skills garnered through the IAC position were helpful. He noted that these skills have been beneficial in his career, beyond positions involving energy. He commented that the lead professor in the IAC program is key to its success. He indicated that his University of Dayton experience was excellent due in great measure to the professor leading the effort. Finally, he was pleased that he participated in the program, although he has not pursued energy efficiency in every position held during his career. The other alumnus responded that the IAC was a "fantastic" program where he gained a great deal of practical information.

Initial job responsibilities were not related to energy-efficiency but have since transitioned to positions involving energy-efficiency. Five IAC alumni who responded to our survey did not embark on an energyrelated career in their first position but moved into an energy position later (Table 9). The five have held, on average, slightly less than three positions in their careers since their IAC experience. The average length of a position has been 3.3 years. However, of those positions that involved energy-efficiency, the average length of tenure has been 4.0 years. 
Employers for positions involving energy include consulting firms, university, large industry and/or manufacturing facility, or an energy service company. Some of the five have changed employers during their careers, while others have remained with the same firm but their job responsibilities changed. Two have held positions in consulting firms throughout their career, while others have gone from university settings to consulting firms to large industrial facilities. Their specific methods of influencing energy efficiency - within four of the six career path categories - energy assessments; teaching and training; construction, operation, maintenance, or repair; and design — include such activities as:

- Working with manufacturing plants and hospitals with regard to the most efficient control system, including assessments (energy assessments).

- Conducting assessments (energy assessments).

- Making recommendations on changes in energy design (design).

- Supervising construction of new energy systems (construction, operation, maintenance, or repair).

- Training students on conducting assessments (teaching and training).

- Providing seminar training on energy-efficiency (teaching and training).

- Facility assessments, renovations, and purchasing of energy equipment (energy assessments).

- Implementing energy-efficiency packages (construction, operation, maintenance, or repair).

- Incorporating energy efficient equipment into HVAC design (construction, operation, maintenance, or repair).

- Replacing old equipment with high efficient equipment into HVAC design (construction, operation, maintenance, or repair).

Even though the initial appointment in one respondent's career did not involve energy-efficiency, the respondent indicated that the IAC training was extremely relevant to his position because it provided the ability to understand manufacturing processes and energy consumption patterns. He said his IAC experience exposed him to various rate structures in the utility industry and gave him the ability to explain rate structures to clients and the skill to understand the manufacturing process and energy consumption patterns in a plant during his first career position. He commented, as did others who participated in the survey, that the ability to leave the classroom and move into an industrial setting was beneficial. Other respondents indicated that:

- Those involved with IAC programs were upper caliber students.

- An IAC director was influential in the student's career.

- They would recommend the IAC program to other students.

- Working for the IAC was a wonderful opportunity to learn a wide variety of solutions to engineering problems regarding energy saving issues.

Entire career has involved jobs with energy-efficiency responsibilities. Some $58 \%$ of our respondents (19) have spent their entire careers devoted to energy-efficiency. The average length of position in energy since their IAC experience is 9.84 years, while average number of positions held is 3.0 (Table 9). Presented next is years since graduation. One alumnus reported being involved with energy-efficiency activities 20 years after graduation. Based on this finding, it can be extrapolated that some IAC alumni could be involved with energy-efficiency their entire careers, until retirement, covering a span of 40 years or more.

Employers included universities, large industrial/manufacturing facilities, consulting companies, government agencies, electric utilities, research and development firms, energy service companies, large commercial businesses, and construction and design firms. Respondents' methods of influencing energyefficiency over the course of their careers fall into the following methods: (1) energy assessments, (2) teaching/training, (3) outreach or technology transfer, (4) design, (5) construction, operation, 
maintenance, or repair, and (6) research and financial evaluation. More specific alumni descriptions include:

- Recommended and implemented energy efficient repairs to heating and air conditioning system (construction, operation, maintenance, or repair).

- Calibrated equipment related to energy use (construction, operation, maintenance, or repair).

- Wrote energy modeling software for DOE (outreach and technology transfer);

- Performed assessments for commercial customers (energy assessments);

- Were responsible for efficiency programs for a university with 8 million square feet of buildings (construction, operation, maintenance, or repair).

- Researched and developed energy-efficiency technologies, practices, and strategies for the purpose of technology transfer, deployment, and training (research and financial evaluation and outreach and technology transfer);

- Performed engineering review for energy-efficiency projects for utility rebates for commercial sector (research and financial evaluation).

- Performed engineering review for utility rebates for commercial sector (research and financial evaluation).

- Performed assessments (about 25 plants per year) and write reports (energy assessments).

- Taught energy-related fundamentals of air conditioning design (teaching and training).

- Designed electric power plants (design); and

- Advised electric service customers regarding building design including but not limited to energyefficiency and wise use of electrical energy in particular (design).

When asked if they had any comments about their IAC experience, most respondents credited the IAC program with helping them gain employment and the technical ability to pursue energy-efficiency. Specific comments included:

- "Assisted in finding employment."

- "Provided excellent base for energy-efficiency work pursued in my career."

- "I have worked almost exclusively in the field of energy-efficiency and energy management since my involvement in 1981. Besides serving the industrial sector by performing a useful and cost-effective service, the EADC/IAC is an excellent method to provide relevant and useful training to new engineering students. I have seen several companies use local IACs as recruiting centers because they recognize that the engineers graduating from these programs are more productive than graduates without IAC experience."

- "Affected my principles and lifestyle choices, as I wish to minimize my environmental footprint."

- "Worthwhile experience."

- "Energy savings may be quantifiable but this program also shaped my professional career, much more difficult to quantify."

- "Clearly the program was vital for my professional development in the energy engineering field."

- "It was the most relevant single experience in my college career. It was also directly responsible for me getting hired at my first job out of school." 
Table 9. Summary of energy-efficiency work

\begin{tabular}{|c|c|c|c|}
\hline & $\begin{array}{l}\text { Initial energy- } \\
\text { efficiency } \\
\text { responsibilities }\end{array}$ & $\begin{array}{l}\text { Later energy-efficiency } \\
\text { responsibilities }\end{array}$ & $\begin{array}{l}\text { Entire career energy-efficiency } \\
\text { responsibilities }\end{array}$ \\
\hline No. of observations & 2 & 5 & 19 \\
\hline $\begin{array}{l}\text { Avg. no. positions } \\
\text { held }\end{array}$ & 3 & 2.8 & 3.0 \\
\hline $\begin{array}{l}\text { Avg. length of } \\
\text { positions in energy }\end{array}$ & 3.0 years & 4.0 years & 9.8 years \\
\hline $\begin{array}{l}\text { Years since } \\
\text { graduation: mean } \\
(\min -\mathbf{m a x})\end{array}$ & $12(7-16)$ & $9(8-10)$ & $11(7-15)$ \\
\hline Employers & $\begin{array}{l}\text { Small, medium } \\
\text { industrial/manufacturin } \\
\mathrm{g} \\
\cdot \text { University, college, } \\
\text { other post-secondary } \\
\text { institution }\end{array}$ & $\begin{array}{l}\cdot \text { Consulting } \\
\cdot \text { Energy service company } \\
\cdot \text { Large } \\
\text { industrial/manufacturing } \\
\cdot \text { University, college, other } \\
\text { post-secondary institution }\end{array}$ & $\begin{array}{l}\text { - Construction and/or design } \\
\text { - Consulting } \\
\text { - Electric power/utility } \\
\text { - Energy service company } \\
\text { - Government (federal, state, or local) } \\
\text { - Large commercial business } \\
\text { - Large industrial/manufacturing } \\
\text { - University, college, other post-secondary } \\
\text { institution }\end{array}$ \\
\hline $\begin{array}{l}\text { Job responsibility } \\
\text { categories }\end{array}$ & $\begin{array}{l}\cdot \text { Engineering } \\
\text { management } \\
\cdot \text { Productivity/process } \\
\text { engineering }\end{array}$ & $\begin{array}{l}\cdot \text { Business management } \\
\cdot \text { Consultant } \\
\cdot \text { Engineering management } \\
\cdot \text { Project engineer/project } \\
\text { manager } \\
\cdot \text { Research and development } \\
\cdot \text { Other - product } \\
\text { development }\end{array}$ & $\begin{array}{l}\cdot \text { Analyst } \\
\cdot \text { Business management } \\
\cdot \text { Consultant } \\
\cdot \text { Education/training } \\
\cdot \text { Engineering management } \\
\cdot \text { Facilities management } \\
\cdot \text { Project engineer/project manager } \\
\cdot \text { Research and development } \\
\cdot \text { Sales } \\
\cdot \text { Technician } \\
\cdot \text { Other - product development }\end{array}$ \\
\hline $\begin{array}{l}\text { Methods of } \\
\text { influencing energy } \\
\text { efficiency }\end{array}$ & Energy assessments & $\begin{array}{l}\text { - Construction, operation, } \\
\text { maintenance, or repair } \\
\cdot \text { Energy assessments } \\
\cdot \text { Teaching/training }\end{array}$ & $\begin{array}{l}\text { Construction, operation, maintenance, or } \\
\text { repair } \\
\cdot \text { Design } \\
\cdot \text { Energy assessments } \\
\cdot \text { Outreach and technology transfer } \\
\cdot \text { Research and fiscal management } \\
\cdot \text { Teaching and training }\end{array}$ \\
\hline $\begin{array}{l}\text { Relevance of IAC } \\
\text { experience to } \\
\text { positions involving } \\
\text { energy }\end{array}$ & Extremely Relevant & $\begin{array}{l}\cdot \text { Relevant } \\
\cdot \text { Extremely relevant }\end{array}$ & $\begin{array}{l}\cdot \text { Relevant } \\
\cdot \text { Very relevant } \\
\cdot \text { Extremely relevant }\end{array}$ \\
\hline $\begin{array}{l}\text { Organizational } \\
\text { hierarchy for current } \\
\text { position }\end{array}$ & $\begin{array}{l}\cdot \text { Entry level } \\
\cdot \text { First-level supervisor }\end{array}$ & $\begin{array}{l}\cdot \text { First-level supervisor } \\
\cdot \text { Middle management } \\
\cdot \text { Top management }\end{array}$ & $\begin{array}{l}\cdot \text { Entry level } \\
\cdot \text { First-level supervisor } \\
\cdot \text { Middle management } \\
\cdot \text { Top management }\end{array}$ \\
\hline
\end{tabular}


We collected data on all the jobs held by the 19 alumni who have spent their entire careers in positions related to energy-efficiency. These 19 have followed 11 different career paths up to this point, which are:

- Began in and have stayed in an entry-level position (2) (average years in work force: 8).

- Began in and have stayed in a first-level supervisory position (2) (average years in work force: 7).

- Began in entry-level position and moved to first-level supervisory position (4) (average years in work force: 10).

- Began in entry-level position, moved to first-level supervisory position and then to middlemanagement position (1) (average years in work force: 10).

- Began in entry-level position and moved to middle-management position (3) (average years in work force: 10).

- Began in first-level supervisory position and moved to middle-management position (2) (this path includes one individual who started as an assistant professor and moved to associate professor) (average years in work force: 8)

- Began in first-level supervisory position, moved to middle-management position, then to first-level supervisory position (1) (average years in work force: 17).

- Began in entry-level position, moved to middle-management position, then to top-management position (1) (average years in work force: 7).

- Began in entry-level position, moved to top-management position, then to middle-management position (with a change in employer) (1) (average years in work force: 10).

- Began in middle-management position, moved to first-level supervisory position (with a change in employer), then moved to entry-level position (1) (average years in work force: 9).

- Began in entry-level position, moved to middle-management position, moved to entry-level position, then moved to first-level supervisory position (1) (average years in work force: 19).

These data indicate that $53 \%$ of these alumni are currently working at either an entry-level position or first-level supervisory position with the balance holding positions in middle and top management. Three alumni have actually moved down the organizational hierarchy. Figure 1 indicates, interestingly enough, that there is no relationship between years in the workforce and current positions in the career hierarchy. Most alumni have moved up the hierarchy but did so in about the same time as many who have not moved up much at all. Also, the two most senior alumni in the sample have moved up and down the career ladder over the years.

Figure 1. Senior alumni career paths over time

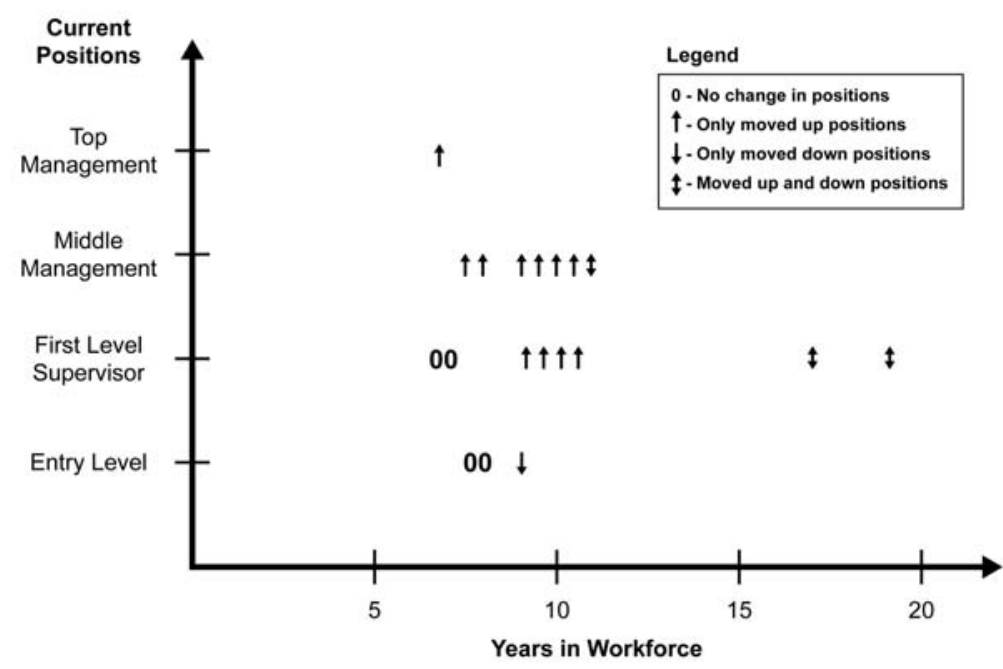


It is also interesting to examine how methods of influencing energy efficiency have changed over alumni's careers. As expected, the first jobs of the majority of these alumni encompassed energy assessments. Only seven alumni have had careers in which methods used to influence energy efficiency have not changed. These seven are conducting energy assessments, teaching and research (academic position), operation and maintenance (primarily of HVAC equipment) or design. Five of the seven have not changed employers; two did but maintained the same method of influencing energy decisions (conducting assessments). Most of the employers are universities (4). One senior alumnus obtained initial employment at a consulting firm, moved to an electric power/utility, then a large industrial/manufacturing firm, and finally to a consulting firm. The sixth person has been with one employer: a construction/design firm. The seventh person has worked for two consulting firms, then a university, and currently an electric power utility. Graduation dates for receipt of an initial degree while participating in the IAC program are 1985 (1), 1990 (1), 1991 (1), and 1994 (4).

Of the remaining twelve who did change methods of influencing energy efficiency during their careers, their graduation dates range from 1990 to 1995 and the methods run the gamut (Table 10). Employers have been:

- Consulting firms.

- Government (federal, state, local).

- Electric power/utility.

- University, college, other post-secondary institution.

- Large industrial/manufacturing.

- Research and development.

- Energy service company.

- Large commercial or business.

- Construction and/or design.

- Other (controls company).

Table 10. Changes in methods of influencing energy efficiency over career

\begin{tabular}{lc}
\hline \multicolumn{1}{c}{ Methods } & $\begin{array}{c}\text { Number of } \\
\text { Observations }\end{array}$ \\
\hline $\begin{array}{l}\text { Changed from energy assessments to construction, operation, maintenance, or repair } \\
\text { Changed from energy assessments to outreach and technology transfer to research and fiscal management } \\
\text { to outreach and technology transfer }\end{array}$ & 1 \\
Changed from energy assessments to teaching and training to research and financial evaluation & 1 \\
$\begin{array}{l}\text { Changed from research and financial evaluation to energy assessments with research and financial } \\
\text { evaluation }\end{array}$ & 1 \\
Changed from energy assessments to research and financial evaluation & 2 \\
$\begin{array}{l}\text { Changed from energy assessments to construction, operation, maintenance, or repair to outreach and } \\
\text { technology transfer to research and financial evaluation }\end{array}$ & 1 \\
$\begin{array}{l}\text { Changed from research and financial evaluation to energy assessments to construction, operation, } \\
\text { maintenance, or repair to energy assessments to research and financial evaluation } \\
\text { Changed from energy assessments to design } \\
\text { Changed from energy assessments to design and technology transfer }\end{array}$ & 1 \\
\hline
\end{tabular}


Table 11 provides information on methods used by the four organizational levels in the organization addressed in this analysis: entry-level position, first-level supervisory, middle management, and top management. We made several interesting observations. First, as expected, most entry-level and firstlevel supervisory positions held by senior IAC alumni involve energy assessments. Somewhat surprisingly, job descriptions for middle and top management include energy assessments. This is a sign that energy-efficiency activities are receiving attention at the higher levels of organizations. It may also indicate that there is an opportunity for the IAC program to craft a continuing education program aimed at management issues associated with conducting energy assessments.

Table 11. Methods of influencing energy efficiency by positions in organizations

\begin{tabular}{|c|c|}
\hline Hierarchical Position & $\begin{array}{c}\text { Method of Influencing Energy Efficiency/ } \\
\text { Number of Observations }\end{array}$ \\
\hline Entry-level position & $\begin{array}{l}\cdot \text { Energy assessments }(13) \\
\cdot \text { Outreach and technology transfer }(1) \\
\cdot \text { Construction, operation, maintenance, or repair }(2) \\
\cdot \text { Research and financial evaluation }(4) \\
\cdot \text { Design (1) }\end{array}$ \\
\hline First-level supervisor & $\begin{array}{l}\cdot \text { Research and financial evaluation }(8) \\
\cdot \text { Outreach and technology transfer }(3) \\
\cdot \text { Energy assessments }(12) \\
\cdot \text { Teaching and training }(2) \\
\cdot \text { Construction, operation, maintenance, or repair (1) } \\
\cdot \text { Design (3) }\end{array}$ \\
\hline Middle management & $\begin{array}{l}\cdot \text { Energy assessments }(8) \\
\cdot \text { Construction, operation, maintenance, or repair }(2) \\
\cdot \text { Research and financial evaluation }(3) \\
\cdot \text { Teaching and training }(1) \\
\cdot \text { Outreach and technology transfer }(1) \\
\cdot \text { Design (3) }\end{array}$ \\
\hline Top management & $\begin{array}{l}\cdot \text { Energy assessments (2) } \\
\cdot \text { Teaching and training (1) } \\
\cdot \text { Research and financial evaluation (1) }\end{array}$ \\
\hline
\end{tabular}

Another interesting observation concerns changing job responsibilities as individuals move up in their organizations. There is some indication that research and financial evaluation responsibilities become more prominent as people move from entry-level to supervisory positions. Research and financial evaluation could be another focus for a continuing education program aimed at IAC alumni. 


\section{CONCLUSIONS}

The IAC program appears to be successful in diffusing energy-efficiency knowledge to its alumni. The fact that almost $80 \%$ of the responding alumni are pursuing energy-efficiency at this point in their careers evidences this diffusion. That $58 \%$ of the respondents have spent their entire careers in energyefficiency-related work is further support of the diffusion and represents a remarkable accomplishment for the IAC program. Most of the respondents who have spent their careers in energy-related functions credit the IAC program with providing the experience and knowledge necessary to gain and maintain employment in energy-efficiency positions. Moreover, the fact that alumni have changed employers and have moved about within organizations has further diffused the energy-efficiency knowledge and expertise. Although in this task we did not ask participants to quantify energy savings, those with energy backgrounds indicated that energy savings indeed occurred.

IAC alumni use different methods to influence decisions, as should be expected. For example, they influence energy-efficiency by teaching undergraduate and graduate students about design, conducting energy assessments in combination with recommendations, and observing implementation of energyefficiency strategies within their own firms. The IAC experience appears to have offered a breadth of methods for the alumni to use in influencing decisions.

The IAC program is primarily targeted toward engineering skills as evidenced by the fact that all the interviewed alumni graduated with a degree in a field of engineering. Several have been promoted but relatively few have moved beyond first-level supervisory positions. In reaction to this observation, IAC could consider expanding its curriculum to include management classes. IAC could also consider offering some form of continuing education/professional training for IAC alumni. Topics for continuing education could include: a review of new energy-efficiency technologies, techniques, and processes; management of energy assessment activities; and management of research and financial activities.

Finally, several changes in the operation of the IAC program are currently being implemented to improve the prospects for students to obtain and keep jobs in energy efficiency. Efforts are underway to attract corporate recruiters to the IAC program, by working through university career offices. Another effort is outreach to the professional community to allow student IAC-based school work to contribute towards professional certifications. DOE now issues certificates of accomplishment to students who have participated in the program, to support recognition of IAC experience by state licensure boards. A third change to be implemented is to improve and administer an alumni database. This database could be used by alumni to contact other alumni about energy efficiency positions. Of course, the database would also help DOE contact alumni about new programs and to periodically take stock of their accomplishments. Center directors should take a strong role in this task, because they will have the best opportunity to establish continuing relationships with alumni. Lastly, ways are needed to include current students in discussions about the direction of the IAC Program. One idea that is currently being implemented is called the Student Steering Committee, which would allow student representatives from IACs to make suggestions not only to the Center Directors but to DOE as well.

\section{ACKNOWLEDGMENTS}

We offer thanks to Jonathan Overly and Greg Harrell for their comments on an earlier version of this report. 


\section{REFERENCES}

Folz, D. H. 1996. Survey Research for Public Administration. Thousand Oaks, CA: Sage Publications.

Martin, M., B. Tonn, R. Schmoyer, J. Overly, S. Schexnayder, and D. Johnson. 1999. Industrial Assessment Center Program Impact Evaluation. Oak Ridge, TN: Oak Ridge National Laboratory, ORNL/CON-473. 

APPENDIX A. IAC (EADC) ALUMNI SURVEY 



\section{IAC (EADC) ALUMNI SURVEY}

\section{SURVEY ADMINISTRATOR}

The University of Tennessee

Energy, Environment and Resources Center

DELIVERY MECHANISM

Telephone interview/Open discussion/E-mail/Mail

\section{PURPOSE OF SURVEY}

The University of Tennessee has received a grant from the U.S. Department of Energy to gather information about savings persistence of alumni (particularly those graduating in 1995 or prior) of DOE's Energy Analysis and Diagnostic Center Program. The survey will focus on two issues: (1) what percent of EADC alumni address energy concerns over their career and (2) different methods of influencing energy conservation decisions over the years.

The Office of Industrial Technologies, located within the US Department of Energy, is interested in gathering information about the savings persistence of senior alumni of DOE's Industrial Assessment Center (IAC) (formerly Energy analysis and Diagnostic Center) Program. In following with the Government Performance and Results Act of 1993, the IAC is implementing a continuous quality improvement effort. The purpose of this survey is to support this effort by developing a qualitative understanding of the different ways that alumni are involved in saving energy over the course of their professional careers, and how the IAC/EADC program helped them to achieve energy savings over time.

\section{CONFIDENTIALITY}

Response to this survey is voluntary and all responses will be held in complete confidentiality. Responses will be collected and the respondent's name and other identifying information will be separated from his/her responses for reporting purposes.

Questions 1-4 pertain to the school where you participated in the EADC Program.

1. What year did you graduate from the school?

2. What was your degree?

3. What was your field of study?

4. What school did you graduate from? 
5. Which personal skills and capabilities (i.e., time management, communication, technical knowledge, etc.) were enhanced as a result of your participation in the EADC Program?

6. Please list any professional associations to which you belong.

7. What registrations and/or certifications have you received?

8. How many positions have you held during your career? Please include different positions held within the same organization and positions with different organizations.

Note to Respondent: The following questions are going to be asked about positions you have held in your career. If you have held more than 6 positions since your participation in EADC, please list positions held about every three years.

\section{POSITION NO. 1}

9. Please provide starting and ending years for position no. 1.

Start (year)

End (year)

10. Please provide a name for this position

11. What type of employer did/do you work for in position no. 1? Check most appropriate one.

[ ] Large Industrial/Manufacturing

[ ] Small, Medium Industrial/Manufacturing

[ ] Large Commercial or Business

[ ] Small, Medium Commercial or Business

[ ] Electric Power/Utility

[ ] Energy Service Company

[ ] Construction and/or Design 
[ ] Government (federal, state, local)

[ ] Non-Profit Organization

[ ] Consulting

[ ] University, College, other Post-Secondary Institution

[ ] Elementary or Secondary School

[ ] Research and Development

[ ] Consumer or Private Citizen

[ ] Other, please specify

12. Please check which job title most closely matches your job responsibilities during your tenure in position no. 1.

[ ] Engineering management

[ ] Business management

[ ] Education/training

[ ] Architect

[ ] Project engineer/Project Manager

[ ] Product engineer/Product Manager

[ ] Research and development

[ ] Productivity/process engineering

[ ] Technician

[ ] Analyst

[ ] Facilities Management

[ ] Technology Support

[ ] Sales

[ ] Marketing

[ ] Other, please specify

13. Please check which description most closely matches how position no. 1 fit in that organization's hierarchy.

[ ] Entry-level technician, engineer, analyst

[ ] First-level supervisor, project manager, group leader

[ ] Middle management, division director

[ ] Upper management, Vice President

[ ] Top management, CEO, COO, CIO

[ ] Other, please specify

14. Please describe your involvement with energy-efficiency during your tenure in position no. 1 (i.e., conducted audits, approved purchases, implemented energy-efficiency strategies, etc.). Qualitatively, what were the impacts upon saving energy? 
15. How relevant was your EADC Program training to position no. 1?

[ ] Extremely relevant

[ ] Very relevant

[ ] Relevant

[ ] Barely relevant

[ ] Not relevant

Other Comments:

\section{POSITION NO. 2}

9. Please provide starting and ending years for position no. 2 .

Start (year)

End (year)

10. Please provide a name for this position

11. What type of employer did/do you work for in position no. 2? Check most appropriate one.

[ ] Large Industrial/Manufacturing

[ ] Small, Medium Industrial/Manufacturing

[ ] Large Commercial or Business

[ ] Small, Medium Commercial or Business

[ ] Electric Power/Utility

[ ] Energy Service Company

[ ] Construction and/or Design

[ ] Government (federal, state, local)

[ ] Non-Profit Organization

[ ] Consulting

[ ] University, College, other Post-Secondary Institution

[ ] Elementary or Secondary School

[ ] Research and Development

[ ] Consumer or Private Citizen

[ ] Other, please specify

12. Please check which job title most closely matches your job responsibilities during your tenure in position no. 1 .

[ ] Engineering management

[ ] Business management

[ ] Education/training

[ ] Architect

[ ] Project engineer/Project Manager

[ ] Product engineer/Product Manager

[ ] Research and development

[ ] Productivity/process engineering

[ ] Technician

[ ] Analyst

[ ] Facilities Management

[ ] Technology Support

[ ] Sales

[ ] Marketing

[ ] Other, please specify 
13. Please check which description most closely matches how position no. 2 fit in that organization's hierarchy.

[ ] Entry-level technician, engineer, analyst

[ ] First-level supervisor, project manager, group leader

[ ] Middle management, division director

[ ] Upper management, Vice President

[ ] Top management, CEO, COO, CIO

[ ] Other, please specify

14. Please describe your involvement with energy-efficiency during your tenure in position no. 2

(i.e., conducted audits, approved purchases, implemented energy-efficiency strategies,

etc.). Qualitatively, what were the impacts upon saving energy?

15. How relevant was your EADC Program training to position no. 2?

[ ] Extremely relevant

[ ] Very relevant

[ ] Relevant

[ ] Barely relevant

[ ] Not relevant

Other Comments:

\section{POSITION NO. 3}

9. Please provide starting and ending years for position no. 3 .

Start (year)

End (year)

10. Please provide a name for this position

11. What type of employer did/do you work for in position no. 3? Check most appropriate one.

[ ] Large Industrial/Manufacturing

[ ] Small, Medium Industrial/Manufacturing

[ ] Large Commercial or Business

[ ] Small, Medium Commercial or Business

[ ] Electric Power/Utility

[ ] Energy Service Company

[ ] Construction and/or Design

[ ] Government (federal, state, local)

[ ] Non-Profit Organization 

[ ] Consulting
[ ] University, College, other Post-Secondary Institution
[ ] Elementary or Secondary School
[ ] Research and Development
[ ] Consumer or Private Citizen
[ ] Other, please specify

12. Please check which job title most closely matches your job responsibilities during your tenure in position no. 3 .
[ ] Engineering management
[ ] Business management
[ ] Education/training
[ ] Architect
[ ] Project engineer/Project Manager
[ ] Product engineer/Product Manager
[ ] Research and development
[ ] Productivity/process engineering
[ ] Technician
[ ] Analyst
[ ] Facilities Management
[ ] Technology Support
[ ] Sales
[ ] Marketing
[ ] Other, please specify

13. Please check which description most closely matches how position no. 3 fit in that organization's hierarchy.

[ ] Entry-level technician, engineer, analyst

[ ] First-level supervisor, project manager, group leader

[ ] Middle management, division director

[ ] Upper management, Vice President

[ ] Top management, CEO, COO, CIO

[ ] Other, please specify

14. Please describe your involvement with energy-efficiency during your tenure in position no. 3 (i.e., conducted audits, approved purchases, implemented energy-efficiency strategies, etc.). Qualitatively, what were the impacts upon saving energy? 
15. How relevant was your EADC Program training to position no. 3 ?

[ ] Extremely relevant

[ ] Very relevant

[ ] Relevant

[ ] Barely relevant

[ ] Not relevant

Other Comments:

\section{POSITION NO. 4}

9. Please provide starting and ending years for position no. 4.

$$
\text { Start }
$$
(year)

End (year)

10. Please provide a name for this position

11. What type of employer did/do you work for in position no. 4? Check most appropriate one

[ ] Large Industrial/Manufacturing

[ ] Small, Medium Industrial/Manufacturing

[ ] Large Commercial or Business

[ ] Small, Medium Commercial or Business

[ ] Electric Power/Utility

[ ] Energy Service Company

[ ] Construction and/or Design

[ ] Government (federal, state, local)

[ ] Non-Profit Organization

[ ] Consulting

[ ] University, College, other Post-Secondary Institution

[ ] Elementary or Secondary School

[ ] Research and Development

[ ] Consumer or Private Citizen

[ ] Other, please specify

12. Please check which job title most closely matches your job responsibilities during your tenure in position no. 1.

[ ] Engineering management

[ ] Business management

[ ] Education/training

[ ] Architect

[ ] Project engineer/Project Manager

[ ] Product engineer/Product Manager

[ ] Research and development

[ ] Productivity/process engineering

[ ] Technician

[ ] Analyst

[ ] Facilities Management

[ ] Technology Support

[ ] Sales

[ ] Marketing

[ ] Other, please specify 
13. Please check which description most closely matches how position no. 4 fit in that organization's hierarchy.

[ ] Entry-level technician, engineer, analyst

[ ] First-level supervisor, project manager, group leader

[ ] Middle management, division director

[ ] Upper management, Vice President

[ ] Top management, CEO, COO, CIO

[ ] Other, please specify

14. Please describe your involvement with energy-efficiency during your tenure in position no. 4

(i.e., conducted audits, approved purchases, implemented energy-efficiency strategies,

etc.). Qualitatively, what were the impacts upon saving energy?

15. How relevant was your EADC Program training to position no. 4 ?

[ ] Extremely relevant

[ ] Very relevant

[ ] Relevant

[ ] Barely relevant

[ ] Not relevant

Other Comments:

\section{POSITION NO. 5}

9. Please provide starting and ending years for position no. 5 .

Start (year)

End (year)

10. Please provide a name for this position

11. What type of employer did/do you work for in position no. 5? Check most appropriate one.

[ ] Large Industrial/Manufacturing

[ ] Small, Medium Industrial/Manufacturing

[ ] Large Commercial or Business

[ ] Small, Medium Commercial or Business

[ ] Electric Power/Utility

[ ] Energy Service Company

[ ] Construction and/or Design

[ ] Government (federal, state, local)

[ ] Non-Profit Organization

[ ] Consulting

[ ] University, College, other Post-Secondary Institution

[ ] Elementary or Secondary School

[ ] Research and Development 


\section{[ ] Consumer or Private Citizen}

[ ] Other, please specify

12. Please check which job title most closely matches your job responsibilities during your tenure in position no. 1.
[ ] Engineering management
[ ] Business management
[ ] Education/training
[ ] Architect
[ ] Project engineer/Project Manager
[ ] Product engineer/Product Manager
[ ] Research and development
[ ] Productivity/process engineering
[ ] Technician
[ ] Analyst
[ ] Facilities Management
[ ] Technology Support
[ ] Sales
[ ] Marketing
[ ] Other, please specify

13. Please check which description most closely matches how position no. 5 fit in that organization's hierarchy.

[ ] Entry-level technician, engineer, analyst

[ ] First-level supervisor, project manager, group leader

[ ] Middle management, division director

[ ] Upper management, Vice President

[ ] Top management, CEO, COO, ClO

[ ] Other, please specify

14. Please describe your involvement with energy-efficiency during your tenure in position no. 5 (i.e., conducted audits, approved purchases, implemented energy-efficiency strategies, etc.). Qualitatively, what were the impacts upon saving energy?

15. How relevant was your EADC Program training to position no. 5 ?

[ ] Extremely relevant

[ ] Very relevant

[ ] Relevant

[ ] Barely relevant

[ ] Not relevant

Other Comments: 


\section{POSITION NO. 6}

9. Please provide starting and ending years for position no. 6 .

Start (year)

End (year)

10. Please provide a name for this position

11. What type of employer did/do you work for in position no. 6? Check most appropriate one.

[ ] Large Industrial/Manufacturing

[ ] Small, Medium Industrial/Manufacturing

[ ] Large Commercial or Business

[ ] Small, Medium Commercial or Business

[ ] Electric Power/Utility

[ ] Energy Service Company

[ ] Construction and/or Design

[ ] Government (federal, state, local)

[ ] Non-Profit Organization

[ ] Consulting

[ ] University, College, other Post-Secondary Institution

[ ] Elementary or Secondary School

[ ] Research and Development

[ ] Consumer or Private Citizen

[ ] Other, please specify

12. Please check which job title most closely matches your job responsibilities during your tenure in position no. 1.

[ ] Engineering management

[ ] Business management

[ ] Education/training

[ ] Architect

[ ] Project engineer/Project Manager

[ ] Product engineer/Product Manager

[ ] Research and development

[ ] Productivity/process engineering

[ ] Technician

[ ] Analyst

[ ] Facilities Management

[ ] Technology Support

[ ] Sales

[ ] Marketing

[ ] Other, please specify

13. Please check which description most closely matches how position no. 6 fit in that organization's hierarchy.

[ ] Entry-level technician, engineer, analyst

[ ] First-level supervisor, project manager, group leader

[ ] Middle management, division director

[ ] Upper management, Vice President

[ ] Top management, $\mathrm{CEO}, \mathrm{COO}, \mathrm{ClO}$

[ ] Other, please specify 
14. Please describe your involvement with energy-efficiency during your tenure in position no. 6 (i.e., conducted audits, approved purchases, implemented energy-efficiency strategies, etc.). Qualitatively, what were the impacts upon saving energy?

15. How relevant was your EADC Program training to position no. 6 ?

[ ] Extremely relevant

[ ] Very relevant

[ ] Relevant

[ ] Barely relevant

[ ] Not relevant

Other Comments:

16. Please provide any comments regarding your EADC experience that you would like to share with IAC leadership:

17. Would you like to remain on the permanent mailing list for EADC/IAC alumni?

Please verify our records on your current contact information: Thank you for effort. 